\title{
Социальная база культурности: объясняют ли Пьер Бурдье, Пол ДиМаджио и другие паттерны участия в культурной жизни российского мегаполиса ${ }^{1}$
}

\author{
М.Е. ИЛЛЕ*, М.М. СОКОЛОВ**
}

\begin{abstract}
*Михаил Евгеньевич Илле - старший преподаватель, кафедра философии и социальных коммуникаций, Санкт-Петербургский университет гражданской авиации; издатель и редактор журнала «Телескоп»: журнал социологических и маркетинговых исследований. Адрес: 190005, Санкт-Петербург, Измайловский пр., 14, комната 508. E-mail: red tel@mail.ru

**Михаил Михайлович Соколов - кандидат социологических наук, профессор, факультет политических наук и социологии, Европейский университет в Санкт-Петербурге. Адрес: 191187, Санкт-Петербург, ул. Гагаринская, д. 3a. E-mail: msokolov@eu.spb.ru
\end{abstract}

Цитирование: Илле М.Е., Соколов М.М. (2018) Социальная база культурности: объясняют ли Пьер Бурдье, Пол ДиМаджио и другие паттерны участия в культурной жизни российского мегаполиса // Мир России. Т. 27. № 2. С. 163-188. DOI: $10.17323 / 1811-038 X-2018-27-2-163-188$

Несмотря на активно дебатируемый вопрос о применимости западной теории к российской действительности, мы находим лишь очень немного случаев, когда эта применимость становилась бы предметом эмпирического исследования. В предлагаемой статье мы сравниваем объяснительную силу пяти конкурируюших теорий культурного потребления на материале Мониторинга культурной жизни Санкт-Петербурга 2005-2011 годов - демонстративного потребления, культурного воспроизводства, культурной мобильности, статусной автономии и плюрализации жизненных стилей. Мы описываем эти теории а затем пробуем извлечь из них предсказания в отношении влияния базовых сочиальных атрибутов на "культурность" индивида. В иелом ожидания, основанные на теориях культурного воспроизводства (Бурдье), хуже всего согласуются с нашими данными; демонстративное потребление и культурная мобильность также дают несколько неточных прогнозов. Наш вывод состоит в том, что

1 Настоящая статья является продолжением статьи «Статусные культуры в эпоху социальной революции. Культурное потребление в Петербурге, 1991-2011», опубликованной в предыдущем номере журнала «Мир России» [Илле, Соколов 2018, с. 159-182]. 
теория статусной автономии остается единственной, которую данные не опровергают, но, возможно, плюрализация жизненных стилей имеет место в младиих поколениях.

Ключевые слова: социология культуры, социология искусства, культурное потребление, социальная стратификация, культурный капитал, социальный статус

Одна из дискуссий, регулярно возобновляемых в российской социологии (как и во всякой иной периферийной или полупериферийной социальной науке), касается применимости “западной” теории к “нашим” реалиям, однако позиции сторон в ней редко подкрепляются эмпирическими аргументами. Часто они носят характер произнесения символа веры, не сопровождаемого никакими наглядными демонстрациями ее истинности. Еще чаще выбор позиции проявляется в выборе одной из линий поведения, которая предполагает, что выбирающий внутренне уже решил для себя вопрос раз и навсегда. Те, кто верит, что П. Бурдье ничего не мог сказать о российском обществе, поскольку «у нас все другое», просто не читают его работы. Те, кто верит, что в России не может произойти ничего, что не снилось бы французскому мудрецу, ищут что-то, к чему подошли бы объяснительные схемы из его книг, и не задаются вопросом, нет ли другой схемы импортного или отечественного исполнения, которая лучше подошла бы к случаю.

Цели этой статьи состоят в том, чтобы сравнить на российском материале объяснительную силу пяти теорий, описывающих потребление традиционной высокой культуры в современных обществах: демонстративного потребления, культурного воспроизводства, культурной мобильности, статусной автономии и жизненных стилей. В первой части статьи мы попробуем систематизировать эти теории, сведя различия между ними к двум основным измерениям, включающим, во-первых, признание или отказ в признании автономии статусной культуры от основанного на собственности и рыночных шансах класса, а во-вторых, степень рефлексивности, которую теория приписывает культурному потреблению. Затем мы опишем следующие из них ожидания в отношении связей между уровнями культурного потребления и несколькими базовыми социальными характеристиками индивида. Далее мы опишем имеющиеся данные, представим статистические расчеты и обсудим следующие из них выводы.

\section{Теоретическая дискуссия - 1.} Автономия vs производность статуса

Одной из центральных проблем теории социальной стратификации является проблема независимости статуса от класса [DiMaggio, Mohr 1985; Chan, Goldthorpe 2004], где класс соответствует совокупности переменных, связанных с положением на рынке труда, обладанием собственностью и экономическими шансами, а статус - образу жизни и престижу, который с этим образом жизни сопряжен. Эти определения намеренно оставлены не слишком конкретными, поскольку нам было важно не просто согласиться с каким-то одним из десятков определений «класса», а найти нечто такое, что объединяет их и позволяет 
противопоставить «статусу» как набору характеристик, связь которых с классом может быть поставлена под вопрос ${ }^{2}$.

Со времен бурдьевистской революции в изучении искусства культурное потребление интересует социологов в основном как элемент статусной культуры ${ }^{3}$, которая наделяет потребителей престижем и позволяет им проводить социальные границы между собой и теми, кому предположительно не хватает каких-то ценных качеств, стоящих за любовью к прекрасному - изысканности, утонченности, возвышенности. В большинстве обществ наблюдается значительная корреляция между классом и статусом: богатые одновременно ведут образ жизни, который пользуется наибольшим почтением. Однако является ли данная тенденция к кристаллизации (пользуясь термином Г. Ленски [Lenski 1956]) результатом взаимного притяжения независимых форм иерархии, или одна из них - иерархия, которая задается соответствием стандартам статусной культуры, - лишь производна от другой, экономического неравенства, и не способна воспроизводиться в отрыве от нее? Прототипом всех теорий производности может считаться теория демонстративного потребления Т. Веблена [Веблен 1984], в которой праздные классы культивируют в себе вкусы, сигнализирующие об их достатке. Гарантирующий наибольшее почтение образ жизни, это, по определению, образ жизни тех, кто находится на вершине экономической иерархии: только они могут позволить себе расходовать деньги и время на утилитарно бесполезные объекты и времяпрепровождение, вроде посещения галерей или получения искусствоведческого образования (технократ Т. Веблен был своего рода американским Базаровым). С точки зрения этой традиции, основная функция искусства как элемента статусной культуры, с одной стороны, сигнализировать, что его аудитории и его патроны занимают привилегированное социальное положение, с другой, служить инструментом закрепления этого положения.

Статусная культура, с точки зрения всех теорий производности, консолидирует социальное неравенство несколькими путями. Во-первых, исходящие от индивида культурные сигналы заставляют окружающих рассматривать его как более или менее желанного партнера для установления всевозможных социальных связей. Те, кто является носителями статусной культуры, могут легко идентифицировать друг друга как партнеров по коммуникации, исключив всех остальных. Во-вторых, символы, становящиеся частью статусной культуры, могут быть по своему характеру более надежными признаками классовых преимуществ, чем просто расточаемое напоказ богатство; в особенности эффективны они с точки зрения истэблишмента, как инструмент исключения нуворишей. Для того чтобы быть полноценным членом статусной культуры, надо вырасти среди ее представителей, а люди, которые быстро заработали много денег, редко способны наверстать отставание в культурном росте.

2 В исследованиях социальной стратификации «статус» используется в двух смыслах - как указание на положение в любом множестве иерархически упорядоченных позиций (в этом смысле может существовать «классовый статус» или «экономический статус») или как указание на особую форму иерархии, которая определяется распределением престижа, и на положение индивида в этой иерархии. Мы придерживаемся второго словоупотребления, поскольку иначе нам пришлось бы изобрести новую неуклюжую категорию, вроде «престижного статуса», чтобы задать интересующий нас вопрос о его отношении с «классовым статусом».

3 Вообще говоря, правильнее было бы говорить о множестве статусных культур, наделяющих своих носителей разным уровнем престижа, а не об одной «статусной культуре», ассоциируемой с высоким престижем. Тем не менее такое словоупотребление широко распространено в исследованиях культурного капитала (начало ему положили, видимо, П. ДиМаджио и Дж. Mop [DiMaggio, Mohr 1985, pp. 1232-1237]), и в дальнейшем мы будем придерживаться именно его. «Статусная культура» - это культура, наделяющая наибольшим престижем. 
Работы П. Бурдье представляют собой иную вариацию на тему производности статуса, которую можно обозначить как теорию культурного воспроизводства. П. Бурдье на первых страницах «Различения» обещает переосмыслить веберовское понятие «статусной группы» (см. ниже) и достигает этого, делая специфический стиль жизни фасадом соответствующего класса [Bourdieu 1984, p. хii]. Общность стиля жизни и диспозиций позволяет исключать тех, кто принадлежит к другой группе, причем делать это в некотором смысле с их согласия. Людям, которые слушают одну музыку, есть о чем поговорить друг с другом, и они естественно отдаляются от тех, кто предпочитает другую музыку. Если вкус совпадает с экономическим классом, то он способствует тому, что циркулирующие по сетям ресурсы (скажем, предложения работы или шансы на возникновение брачного союза) оказываются замкнуты в границах класса. Понятно, что эти ресурсы имеют разную ценность: в одной сети хорошему знакомому предлагают место на автомойке, в другой - в директорате банка.

По П. Бурдье, помимо монополизации шансов, за счет воспитания вкусов высшие классы также легитимируют свое положение. Особую роль здесь играет школа, чьи мнимо универсальные правила поощряют одну систему диспозиций и «наказывают» другую, тем самым приводят детей элиты к успеху, придавая этому успеху ореол меритократичности. Культурность семьи конвертируется в образовательные достижения (учителя выделяют и опекают «умненьких деток»), а освоение культурных кодов, происходящее в школе, обеспечивает доступ к экономическому благополучию и одновременно делает возможным дальнейшее потребление высокой культуры. Надо отметить, что П. Бурдье, кажется, постепенно пересматривал исходное представление о близком к идеальному совпадении класса и статусной культуры: если в работах о культурном потреблении и системе образования рубежа 1960-1970-х гг. обобщенная буржуазия выступала единоличным носителем статусной культуры, то в исследованиях 1970-х гг. (включая «Различение») появилось разграничение фракций элиты с высоким и низким культурным капиталом, ставшее более заметным в трудах 1980-х гг. по отдельным полям. Тем не менее в целом П. Бурдье продолжал настаивать на доминировании экономического капитала и основанной на нем иерархии.

Появление теории, противостоящей теории производности, которая названа в настоящей статье теорией статусной автономии, ассоциируется с М. Вебером, который в своем очерке о теории стратификации [Weber 1978, pp. 300-307] отчетливо противопоставил классы как группы, основанные на обладании собственностью и/или ценными навыками, которые обеспечивают общность экономических шансов, статусным группам как наследственным образованиям, характеризующихся эндогамией, определенным образом жизни и основанным на нем престижем. Статусные группы и классы для М. Вебера были альтернативными формами организации неравенства, которые были способны полностью вытеснять одна другую ${ }^{4}$, но могли и сосуществовать рядом друг с другом, создавая при этом определенные напряжения. В современной Европе преобладают классы, но присутствие некоторых статусных групп еще ощущается (М. Вебер упоминал военных - наследственное прусское юнкерское офицерство).

\footnotetext{
4 По словам М. Вебера, классы полностью отсутствовали, скажем, в Индии, где над всем доминировала статусная кастовая система, и в основном отсутствовали в Европе во времена средневековья.
} 
Статус, основанный на коллективно разделяемых ценностях, был одной из основных объяснительных переменных функционалистской теории стратификации. Самой смелой, возможно, формулировкой в ее рамках стала работа Э. Шилза [Shils 1965], который связал престиж профессиональной группы с существованием непосредственной зависимости выполняемой ею работы с фундаментальными основами космического порядка, «действительно серьезными» вещами. Доктор сопровождает нас в самые драматические моменты нашего существования; ученый раскрывает тайны Вселенной; рекламный агент старается продать людям вещи, которые им, в сущности, не нужны. Даже если последний получает в три раза больше, чем двое первых вместе взятых, что-то заставляет нас сомневаться, утверждает Э. Шиллз, что его существование является в той же мере осмысленным. Неравенство в престиже может не только не вытекать из различий в заработках, но и наоборот: представители профессий, которые считаются более правильными, могут претендовать на большую зарплату.

Возможно, самой влиятельной на сегодняшний день противопоставляющей класс и статус остается схема Дж. Голдторпа и его многочисленных учеников, которая позволяет отнести каждую профессию к классу на основании свойств типичного контракта (интерпретации неоинституциональной экономики Уильямсона) (напр. [Chan, Goldthorpe 2004; Chan, Goldthorpe 2007]). Одновременно каждая профессиональная группа находится где-то на шкале престижа, метрикой которого является положение на шкале социальной дистанции: чем больше шансов, что между представителями двух профессий будет существовать дружба или брачный союз, тем они ближе. Очевидным источником этой идеи здесь, разумеется, стало веберовское описание статусных групп как стремящихся к эндогамности.

Статус, измеренный таким образом, и класс коррелировали, но взаимосвязь оставалась на уровне, который позволял избежать упреков в тавтологии. Кроме того, они оба были взаимосвязаны с заработками, причем класс ожидаемо сильнее, чем статус (корреляция между статусом и доходами составляла 0,55 [Chan, Goldthorpe 2004, p. 392]). Возвращаясь от профессий к искусству, Дж. Голдторп и T. Чан продемонстрировали, что в соответствии с ожиданиями потребление высокой культуры в Британии производно от статуса, но не от класса: при контроле по статусу класс и богатство оказывали лишь очень слабое влияние на вероятность стать слушателем оперы [Chan, Goldthorpe 2007] . $^{\text {. }}$

Своеобразным компромиссом между теориями автономии и производности представляется теория культурной мобильности в том виде, в каком она излагается в работах П. ДиМаджио и некоторых его коллег [DiMaggio, Mohr 1985]. П. ДиМаджио предполагает (также опираясь на указания М. Вебера), что в истории одного сообщества привилегированные слои последовательно приобретают черты вначале класса, а затем - статусной группы. В ходе изменений, приводящих к обновлению элит, новые господствующие группы в капиталистических обществах обычно образуются из нуворишей, однако позже членство в элите начинается все больше определяться через ведение определенного образа жизни, в рамках которого совпадение принадлежности к элите с экономическим богатством размывается. В аналитическом смысле статус относительно автономен от класса.

5 Насколько известно авторам статьи, Дж. Голдторп нигде не отвечает на вопрос о том, откуда берется статус. 
Наконец, последняя группа теорий - теории жизненных стилей - утверждает, что в современных обществах всеобщего благосостояния и свободно циркулирующей информации стили жизни становятся для всех более открытыми, а их ведение в большей степени определяется не принадлежностью к классам или потомственным членством в статусных культурах, а собственным выбором индивидов (см. обзор в [Katz-Gerro 2011]). Корреляции с классовой принадлежностью размываются, в особенности в младших возрастных когортах, но статусная иерархия не возникает параллельно с ней или на ее месте, поскольку все стили жизни считаются более-менее равноценными. Статусная культура исчезает, сменившись множеством статусных культур.

\section{Теоретическая дискуссия - 2. Рефлексивное и нерефлексивное в потреблении}

Помимо первого измерения, противопоставляющего наши теории - отношения класса и статуса и существования иерархического статуса как такового, - существует и второе, важность которого становится особенно очевидной, если мы сравним две теории производности - демонстративного потребления и культурного воспроизводства. Этим измерением является уровень рефлексивности, которым обладают сами агенты по отношению к культурному потреблению и его последствиям. Становится ли принадлежность к статусной культуре результатом более-менее осознанного выбора, и если да, то совершается ли этот выбор с оглядкой на социальную мобильность, которую он может обеспечить? И оценивают ли паттерны культурного потребления других людей исходя из предположения, что они рассматривают культурное потребление как инструмент социальной мобильности? Или культурное поведение возникает из условий социализации и обобщенного социального опыта, которые находятся за пределами сознательных манипуляций?

Мы можем расположить существующие теории в спектре уровней рефлексивности. На нулевом уровне индивиды вообще не отдают себе отчета в социальных последствиях культурного потребления: они ищут общую тему для разговора и радуются, если обнаруживают, что могут поговорить о прочитанных книгах, любимой музыке или просмотренных фильмах, и те, с кем есть о чем поговорить, становятся им ближе. Однако они не имеют никакой наивной социологической теории, раскрывающей подобный механизм возникновения близости или устанавливающей связи между потреблением и принадлежностью к той или иной социальной группе и, соответственно, позволяющей сделать вывод о том, что потребление того или иного искусства более перспективно в смысле формирования полезных связей и избегания бесполезных. Если, тем не менее, вкус формируется под воздействием классового опыта и/или ранней социализации в статусной культуре, то он объективно укрепляет границы между социальными группами, пусть даже без ведома их представителей.

Именно так представляют себе процесс функционирования культурного капитала некоторые современные интерпретаторы П. Бурдье (напр., Д. Хольт, В. Аткинсон или О. Лизардо [Holt 1998; Atkinson 2011; Lizardo, Skiles 2012]), кото- 
рые стремятся избавить П. Бурдье от «стратегирования» ${ }^{6}$ При этом, как говорилось выше, они считают, что высокое происхождение предрасполагает индивидов к формированию широких вкусов, что (совершенно независимо от сознательного намерения установит контакт с себе подобными) приводит к появлению большего числа точек соприкосновения между представителями элиты и делает ее более сплоченной социальной группой.

На следующем (первом) уровне рефлексивности индивиды знают то, о чем на нулевом осведомлен только социолог-наблюдатель: иными словами, они проинформированы (1) о потенциале культуры в установлении связей; (2) о том, что вкусы коррелируют с другими важными социальными атрибутами. Эти атрибуты могут быть (2a) принадлежностью к социальным категориям («я знаю, что радио “Русский шансон” популярнее среди водителей-дальнобойщиков, чем у выпускниц консерватории») или (2б) личностными («я предполагаю, что “Русский шансон” свидетельствует о душевной вульгарности») $)^{7}$. Наличие этих представлений, вероятно, наложит определенный отпечаток на их поведение: зная все это, они будут классифицировать людей на основании собственных вкусов как более или менее желательных для контакта и начнут развить в себе вкус к тому, что позволит им сблизиться с желательными.

Теория культурной мобильности в том виде, в каком она представлена в работах П. ДиМаджио и Дж. Мора [DiMaggio, Mohr 1985; DiMaggio, Mohr 1995], предполагает рефлексивность как минимум первого уровня. П. ДиМаджио и Дж. Мор считали, что в американском обществе индивиды знают о различиях во вкусовых предпочтениях и выигрышах, которые может принести потребление, специфическое для статусных культур (которые частично совпадают с классами, но не идентичны им). Соответственно, мы находим самые высокие уровни потребления всякой культуры среди тех, кто может ожидать наибольшей отдачи от поддержания сети контактов в разных средах, и самое интенсивное потребление специфически высокой культуры среди тех, кому надо контактировать с представителями высшего класса. Данные исследований 1970-1980-х гг. подтверждают оба эти ожидания, показывая, что и всеядность, и интерес к опере наиболее вероятны среди профессионалов, типа врачей, а также коммивояжеров и прочих, занятых прямым взаимодействием с клиентами.

За первым уровнем следует второй, третий и четвертый (например, второй уровень соответствует представлению о том, что другие обладают теми знаниями, которые выше ассоциировались с первым уровнем, и что их культурное потребление нацелено на приобретение статусных выгод, а третий предполагает, что индивид думает, что другие, интерпретируя его действия, исходят из того, что его культурное потребление направлено на достижение статусных выгод. Примером теоретической модели возникновения и динамики статусной культуры, предпола-

\footnotetext{
6 О. Лизардо особо подчеркивает, что именно «стратегирование» отличает П. Бурдье от Т. Веблена и теории культурного воспроизводства от теорий демонстративного потребления.

7 1, 2а и 26 необязательно сопутствуют друг другу. Знание о том, что какое-то искусство привлекает представителей некоторой категории, небезоговорочно должно опираться на развернутые антропологические представления об истоках этих вкусов; можно ограничиться осознанием того, что они просто есть. Аналогично, знание, что чтение популярных книг дает темы для разговора, необязательно должно сопровождаться развернутыми представлениями о том, какие люди читают эти книги. Но мы для простоты будем рассматривать их вместе.
} 
гающей очень высокие уровни рефлексивности, можно назвать переработанную из студенческого эссе раннюю статью Э. Гоффмана [Goffman 1951], в которой он предваряет свои последующие работы по управлению впечатлениями и экспрессивным играм [Goffman 1969]. Следуя по пути, проложенным Т. Вебленом, Э. Гоффман утверждает: в повседневной жизни мы думаем, что другие люди пытаются произвести на нас впечатление, что занимают более благоприятное положение в классовой структуре, чем на самом деле, и оцениваем поступающие от них сигналы с учетом этого ожидания. Именно это и определяет, в конечном счете, возникновение статусной культуры: Э. Гоффман считал, что класс в своей основе - это экономическое образование, а культурность становится важной, поскольку является разновидностью классовых сигналов, которые отличаются высокой надежностью (широкое и бесполезное образование предполагает юность, проведенную в достатке, и, в отличие от бриллиантов, не может быть одолжено, куплено в кредит, украдено или подделано) ${ }^{8}$. Любая теория социального символизма (и культурного потребления постольку, поскольку они пересекаются с предыдущими) неизбежно должна соотноситься с тем уровнем рефлексивности, который они приписывают агентам. Э. Гоффман и П. Бурдье (во всяком случае, в интерпретации О. Лизардо) занимают в данной ситуации два противоположных полюса9. Для нашей нынешней задачи, однако, важно только то, приписываем ли мы агентам хотя бы самый первый из уровней рефлексивности - общее осознание того, что культурное потребление может быть инструментом социальной мобильности.

Различия между пятью перечисленными теоретическими позициями отражены в верхней части таблищы 1 . Вопросительные знаки «???» символизируют, что из теории не следует никакого определенного предсказания в отношении влияния переменной, и любой знак корреляции или ее отсутствие не противоречат ей.

В нижней части таблищы 1 мы попробовали отразить связи, которые каждая из моделей предполагает между базовыми социальными переменным и культурным потреблением. Поскольку данное исследование опиралось на результаты мониторинга, начатого в 1991 г. $^{10}$, мы были ограничены теми переменными, которые были включены в него исходно, тем не менее путем некоторых рассуждений мы можем связать их с нашими моделями.

Культурное потребление и возраст. Более активное участие в культурной жизни в ранней взрослости, на стадии активного формирования социальных связей, говорит в пользу теорий рефлексивности, поскольку допускает, что индивиды думают о предполагаемой отдаче от культурной жизни. Наоборот, то, что культурное потребление не сокращается с возрастом, можно трактовать как свидетельство

\footnotetext{
8 В рамках несколько метафизических теорий классового сознания и классового чутья подобная рефлексивность приписывается целому классу, а не отдельным индивидам, причем уровень рефлексивности, предположительно, повышается с положением группы в социальной иерархии: высшие классы могут манипулировать восприятием низших, но не наоборот. Насколько мы знаем, это положение применительно к символам классового статуса никогда не проверялось эмпирически.

9 Кажется, что в действительности позиция П. Бурдье в том виде, в каком она изложена в «Различении», представляла собой гибридное решение: он приписывал разную степень рефлексивности различным социальным группам, причем самой самосознательной оказалось мелкая буржуазия [Bourdieu 1984, pp. 339-346], которая вследствие своего промежуточного положения чувствительна к классовым сигналам и осознанно стремится имитировать высшую буржуазию, никогда, впрочем, в этом не преуспевая.
}

10 См. подробное описание в [Илле, Соколов 2018]. 
Социальная база культурности: объясняют ли Пьер Бурдье,

Пол ДиМаджио и другие паттерны участия

в культурной жнини российского мегаполиса, стр. 163-188

того, что индивиды следуют социализационной программе без оглядки на последствия для социальной мобильности. Независимый негативный эффект возраста на культурную активность, таким образом, в целом говорит в пользу стратегического потребления и основанных на нем подходов (демонстративное потребление, культурная мобильность), хотя допускает целый ряд оговорок: сокращение активности может вытекать из каких-то иных переменных, например, состояния здоровья и норм, в целом ограничивающих активность старших поколений.

\section{Таблица 1. Теоретические позиции и вытекающие из них эмпирические ожидания}

\begin{tabular}{|c|c|c|c|c|c|}
\hline & $\begin{array}{c}\text { Демон- } \\
\text { стративное } \\
\text { потребление }\end{array}$ & $\begin{array}{c}\text { Культурное } \\
\text { воспроиз- } \\
\text { водство }\end{array}$ & $\begin{array}{l}\text { Культурная } \\
\text { мобильность }\end{array}$ & $\begin{array}{l}\text { Статусная } \\
\text { автономия }\end{array}$ & $\begin{array}{c}\text { Стили- } \\
\text { стический } \\
\text { плюрализм }\end{array}$ \\
\hline \multicolumn{6}{|c|}{ Теоретические позиции } \\
\hline $\begin{array}{l}\text { Отношения } \\
\text { статуса } \\
\text { к классу }\end{array}$ & $\begin{array}{c}\text { Статус } \\
\text { производен }\end{array}$ & $\begin{array}{c}\text { Статус } \\
\text { производен }\end{array}$ & $\begin{array}{c}\text { Частично } \\
\text { производен }\end{array}$ & $\begin{array}{c}\text { Статус } \\
\text { автономен }\end{array}$ & $\begin{array}{c}\text { Статусной } \\
\text { иерархии } \\
\text { не существует }\end{array}$ \\
\hline $\begin{array}{l}\text { Рефлексив- } \\
\text { ность выбора }\end{array}$ & Высокая & Низкая & Высокая & ??? & $? ? ?$ \\
\hline \multicolumn{6}{|c|}{ Эмпирические ожидания } \\
\hline Возраст & $\begin{array}{c}\text { Молодые более } \\
\text { активны }\end{array}$ & Не важен & $\begin{array}{c}\text { Молодые более } \\
\text { активны }\end{array}$ & ??? & $? ? ?$ \\
\hline Образование & $\begin{array}{l}\text { Образованные } \\
\text { более активны }\end{array}$ & $\begin{array}{l}\text { Образованные } \\
\text { более активны }\end{array}$ & $\begin{array}{l}\text { Образованные } \\
\text { более активны }\end{array}$ & $\begin{array}{l}\text { Образованные } \\
\text { более активны }\end{array}$ & $? ? ?$ \\
\hline $\begin{array}{l}\text { Образование } \\
\text { родителей }\end{array}$ & $? ? ?$ & $\begin{array}{c}\text { Дети образо- } \\
\text { ванных родите- } \\
\text { лей активнее }\end{array}$ & $? ? ?$ & $? ? ?$ & Не значимо \\
\hline Доходы & $\begin{array}{l}\text { Богатые } \\
\text { активнее }\end{array}$ & $\begin{array}{c}\text { Богатые } \\
\text { активнее } \\
\text { (опосредовано } \\
\text { образованием) }\end{array}$ & $\begin{array}{l}\text { Богатые } \\
\text { активнее }\end{array}$ & ??? & Не значимо \\
\hline $\begin{array}{l}\text { Возраст * } \\
\text { образование }\end{array}$ & $\begin{array}{c}\text { Для старших } \\
\text { образование } \\
\text { хуже пред- } \\
\text { сказывает } \\
\text { потребление }\end{array}$ & Незначимо & $\begin{array}{c}\text { Для старших } \\
\text { образование } \\
\text { хуже пред- } \\
\text { сказывает } \\
\text { потребление }\end{array}$ & $? ? ?$ & $\begin{array}{c}\text { Для младших } \\
\text { образование } \\
\text { хуже пред- } \\
\text { сказывает } \\
\text { потребление }\end{array}$ \\
\hline $\begin{array}{l}\text { Возраст * } \\
\text { образование } \\
\text { родителей }(\mathrm{OP})\end{array}$ & $\begin{array}{c}\text { Для старших } \\
\text { ОР хуже } \\
\text { предсказывает } \\
\text { потребление }\end{array}$ & Незначимо & $\begin{array}{c}\text { Для старших } \\
\text { ОР хуже } \\
\text { предсказывает } \\
\text { потребление }\end{array}$ & ??? & $? ? ?$ \\
\hline $\begin{array}{l}\text { Возраст * } \\
\text { доходы }\end{array}$ & $? ? ?$ & $\begin{array}{c}\text { Сильная } \\
\text { отрицательная }\end{array}$ & $? ? ?$ & $? ? ?$ & $? ? ?$ \\
\hline $\begin{array}{l}\text { Возраст * доля } \\
\text { объясненной } \\
\text { дисперсии }\end{array}$ & Неизменна & Неизменная & Неизменна & Неизменна & Сокращается \\
\hline
\end{tabular}


Культурное потребление и образование. Обнаружение связи между образованием и культурным потреблением не позволяет нам различить первые четыре теории. Образование наравне с высокой культурой может служить символом классовой принадлежности ${ }^{11}$ или являться элементом целостного образа жизни интеллигенции как статусной группы. Только стилистический плюрализм сможет объяснить, однако, ослабление связи между образованием и культурностью, возникающее вследствие эволюции стилей жизни от прежних шаблонов, в которых существовал ясный типаж «интеллигенции», к новым констелляциям практик. В этом смысле обнаружение отсутствия корреляции между ними будет аргументом в его пользу.

Культурное потребление и доходы. Теория статусной автономии предполагает, что потребление высокой культуры может быть статистически независимо от объема доходов, которые тесно связаны с классом, производным от экономических шансов. В некоторых случаях мы даже можем предполагать отрицательную связь между ними: социетальным почтением пользуются те, кто поставил свое призвание выше мирского благополучия. Обратное, к сожалению, необязательно верно: положительная связь не доказывает гипотезы производности, поскольку (а) экономическое вознаграждение может приводиться в соответствие с престижем (статус первичен, экономическая привилегия вторична); (б) и культурное потребление, и заработок могут быть связаны с какими-то демографическими признаками, например, фазой жизненного цикла (с возрастом люди получают больше и одновременно переключаются на более респектабельные формы досуга); (в) невозможно отрицать, что бедность сказывается на любых формах потребления, и если носители статусной культуры бедствуют, то, вероятно, не смогут принимать в ней регулярное участие. В случае связи с демографическими переменными при статистическом контроле по этим дополнительным признакам связь должна исчезнуть, однако неоднозначность, создаваемая пунктами (а) и (в), представляет собой большую проблему. Демонстрация положительной связи культурного потребления с доходами, таким образом, будет свидетельством лишь против теорий стилистического плюрализма, которые предполагают, что доходы потеряли всякое значение. Демонстрация же отсутствия связи будет, с одной стороны, аргументом против всех трех теорий, предполагающих производность культуры, а с другой, доводом в пользу статусной автономии или плюрализма.

Культурное потребление и образование родителей. С точки зрения нерефлексивных теорий (поскольку культурное потребление определяется ранней социализацией), «культурный климат» семьи, в которой вырос индивид, оказывает прямое влияние на его поведение на протяжении последующей жизни, не опосредуемое такими событиями, как, например, получение высшего образования. Вообще говоря, с точки зрения рефлексивных теорий статистическое влияние родителей также возможно: например, индивиды, выросшие в интеллигентских семьях, развивают конкурентное преимущество, основанное на соответствующем происхождении. Обнаружение отсутствия влияния образования родителей на культурное потребление детей, таким образом, будет аргументом против теории культурно-

11 Т. Веблен бы определил и то, и другое как элемент демонстративного потребления, П. Бурдье рассматривал образование как средство «отмывания» культурного капитала. 
го воспроизводства, а его наличия - против теории стилистического плюрализма, предполагающей, что выбор осуществляется индивидом самостоятельно и не предсказывается факторами вроде происхождения.

Интеракции возраста и доходов. Теории, приписывающие агентам нерефлексивность, предполагают, что предрасположенность к культурному потреблению формируется рано и мало подвержена изменениям в зрелом возрасте. Это означает, что существуют интеракции между возрастом и воздействием иных значимых факторов. В частности, если культурное потребления является производной от экономического положения в период социализации, то мы можем найти более сильную корреляцию между культурной активностью и доходами среди младших, а не среди старших групп, поскольку чем старше индивид, тем слабее связь между его нынешним экономическим положением и экономическим положением его семьи в его подростковые годы, и тем больше роль всевозможных опосредующих факторов ${ }^{12}$. Обнаружение этого эффекта будет решающим аргументом в пользу предположения о переходе классовых символов в новые руки. Если посещение Мариинского театра было символом советского среднего класca, то радикальное перераспределение экономических шансов в последующий период должно привести к тому, что понятая таким образом культурность будет воспроизводиться среди людей старших поколений (которые социализировались до перестройки) вне зависимости от их доходов, но в младших когортах воспроизводить ее будут дети относительно экономически благополучной в настоящее время группы. Вообще говоря, существование этого эффекта не противоречит остальным нашим теориям, но и не следует из них, поэтому обоснованный вывод, который мы сможем сделать с помощью этой переменной, - это опровержение теории воспроизводства, если эффект не наблюдается.

Интеракция возраста и образования. Если культурность и образованность являются сознательной ставкой на ведение определенного образа жизни, сделанной в раннем возрасте, то, возможно, индивиды успеют пересмотреть свой выбор несколько раз на протяжении своей биографии. Но поскольку образование получается лишь однажды, а культурное потребление происходит на протяжении все жизни, это значит, что чем старше индивид, тем слабее корреляции между когда-то сделанным выбором инвестировать время в образование и текущим потреблением. Отсутствие связи может означать существование столь стабильной системы, что причины изменять выбранным однажды стратегиям просто не возникают. Однако ее присутствие будет сильным аргументом в пользу теорий, предполагающих рефлексивность (теорий культурной мобильности или демонстративного потребления).

Интеракция возраста и образования родителей. Аналогично, если участие в статусной культуре рефлексивно, должно сокращаться влияние «культурного климата» семьи [Aschaffenburg, Maas 1995; DiMaggio, Mohr 1995]: образование родителей будет предсказывать культурное потребление тем слабее, чем старше индивид, если мы допускаем, что стратегия культурности избирается сознательно и затем пересматривается.

\footnotetext{
12 Нынешнее положение старших поколений может быть слабо связано с их положением в юности, особенно с учетом радикальных экономических преобразований, которые Россия испытала в 1990-е гг.
} 
Доля объясненной дисперсии. Наконец, большинство теорий стилистического плюрализма не только предполагают, что связь социоструктурных переменных со стилями жизни становится менее значимой, но этот тектонический сдвиг затрагивает в первую очередь младшие поколения. Поскольку все остальные теории по умолчанию допускают, что описываемая ими картина статична, обнаружение того, что в младших когортах доля объясненной дисперсии сокращается, будет аргументом в пользу стилистического плюрализма.

Не все переменные позволяют сравнить эти теории, однако для большинства пар теорий мы находим подобие сильного критического эксперимента, когда следующие из них предсказания прямо противоречат друг другу, и там, где нет «сильного» критического эксперимента, а «слабый» есть, некоторые исходы будут явно опровергать одну из теорий и тем самым служить аргументом в пользу другой. Это касается ситуации с теорией статусной автономии, которая прямо не опровергается ни одним из наблюдений, тем не менее может объяснить многие исходы, в которые не может внести ясность ни одна другая (например, если мы вдруг обнаружим, что богатые потребляют высокую культуру менее активно, чем бедные). Единственной парой теорий, предсказания которых идентичны, оказываются демонстративное потребление и культурная мобильность ${ }^{13}$.

\section{Российский случай}

В советской, а затем российской социологии существует важная традиция исследований культурного потребления, которую можно проследить с 1920-х гг. [Банк, Виленкин 1927; Фохт-Бабушкин 2001]. Как уже говорилось в начале статьи, ни в одном исследовании, насколько нам известно, не делалось попытки систематически проверить перечисленные теории культурного потребления на российском материале.

По контрасту с этим, подходы Дж. Голдторпа к изучению статуса были многократно опробованы на постсоветских случаях, причем оказалось, что, хотя статусная шкала Дж. Голдторпа «работает», она обнаруживает лишь очень слабую корреляцию с доходами (см., напр., данные о венгерском, наиболее изученном примере в [Bukodi 2007; Kraaykamp, Nieuwbeerta 2000]). В России есть важный опыт создания аналогичной шкалы на основании ISSP, который также привел к противопоставлению эндогамных групп интеллигенции (учителя и врачи) и людей физического труда [Бессуднов 2009]. Корреляция положения групп на шкале престижа и средних доходов их представителей также оказалась умеренной $(0,49)$, а на индивидуальном уровне и вовсе незначительной $(0,16)$ [Бессуднов 2009 , c. 107-108]. Статус, оцененный через эндогамность, таким образом, явно не может быть приравнен к экономическому благополучию.

\footnotetext{
13 Они дают конфликтующие предсказания относительно существования «культурной всеядности»: теории демонстративного потребления предполагают, что элитарные группы будут терять интерес к любым объектам или практикам, которые освоят люди попроще, а культурная мобильность допускает, что они будут безразличны к этому. Задокументированное существование «культурной всеядности» в России является аргументом в пользу культурной мобильности [Zavisca 2005; Соколов, Сафонова, Чернеикая 2017].
} 
Из этого нельзя автоматически сделать вывод, что статус независим от класса, поскольку классовая позиция не может быть отождествлена с уровнем доходов. Индивиды, занимающие слаборазличимые позиции на рынке труда, могут иметь различные доходы ${ }^{14}$, и самые разные классовые группы могут включать индивидов, имеющих примерно одинаковые доходы. Тем не менее, видимо, допущение, что классы вовсе не связаны с экономическим благополучием их представителей, кажется противоречием со всеми пониманиями класса. Кроме того, в случае с теориями производной статусной культуры свойством, о наличии которого в ней сигнализирует участие и которое она легитимизирует, является все-таки экономическое благополучие, а не положение на рынке труда как таковое. В этом смысле слабая связь статуса и доходов может пониматься как аргумент в пользу независимости статусной культуры.

В защиту теории производности, однако, можно привести следующий аргумент: расхождение статуса и экономического класса в России - явление временное, результат исторического лага. Брак и выбор профессии предполагают значительную инерцию. Поэтому контуры эндогамных групп могут представлять контуры классовой системы в прошлом, когда врачи, деятели культуры, ученые и преподаватели занимали экономически более благоприятное положение, чем они занимают сейчас. Эта линия защиты предполагает отсылку к теории «школы Селеньи» [Konrad, Szelenyi 1979], в соответствии с которой интеллигенция была господствующим классом в бывших странах государственного социализма. Здесь как раз становится важной интеракция возраста и принадлежности к статусной культуре, о которой говорилось выше: если расхождение класса и статуса - лишь результат исторического лага, то среди младших возрастных групп зазор должен сократиться или исчезнуть.

В предыдущей статье было доказано, что мы можем приблизиться к ответу на вопрос об отношениях класса и статуса, обратившись к изучению исторических ситуаций, в которых классовое положение носителей статусных культур быстро меняется [Илле, Соколов 2018]. Если класс и статус образуют неразрывную пару, то статусная культура прежде доминировавшей, но пришедшей в экономический упадок группы должна или полностью исчезнуть (поскольку участие в ней более не выступает символом экономического благополучия, пропуском в соответствующие социальные сети и инструментом легитимации наследственной привилегии) или быть перехваченной новыми поднимающимися группами. Наши данные показали, что потребление традиционной высокой культуры сократилось лишь незначительно на пике экономического кризиса (являя разительный контраст с невысокой культурой, представленной кинотеатром), оставаясь очень статичным, причем на протяжении всего периода молодежь была самой активной группой потребителей. Все это говорит в пользу представления об относительной автономии статусной культуры от экономического неравенства и с большим числом оговорок в пользу допущения того, что присоединение к ней было вполне осознанной стратегией, выбираемой индивидами в период, когда они могли ожидать наибольшей отдачи от такового. Тем не менее некоторые зафиксированные статистические связи могут вписываться и в альтернативную картину; это в первую очередь касается

14 В схеме Дж. Голдторпа представители одной профессии всегда принадлежат к одной классовой группе, хотя очевидно, что внутри категории, вроде музыкантов или программистов, доходы могут варьироваться бесконечно. 
связи культурного потребления и доходов. Может ли случиться так, что после периода замешательства экономический класс начал непосредственно определять культурное потребление? Целью нашего исследования стало изучение этой и других возможностей.

\section{Данные и методы}

Использованные данные подробно описаны в предыдущей статье [Илле, Соколов 2018], а также в [Илле 2016; Илле 2017]. Мы задавали вопрос представителям репрезентативной выборки петербуржцев старше 18 лет о частоте участия в восьми видах культурной активности за последние 12 месяцев, включающей посещение драмтеатров, музыкальных театров (опера, оперетта), концертов классической, народной и популярной музыки, музеев и выставок, а также кинотеатров и библиотек. Всего было проведено 14 опросов, однако в анализе ниже используются только данные последних 7 волн (2005-2011 гг.), по которым сохранились полные массивы. В результате их слияния мы получили выборку из 8998 случаев.

Помимо сведений об активности, мы также располагали данными о демографических параметрах (пол, возраст), образовании (по трехчастной шкале - незаконченное среднее, среднее (включая среднее профессиональное и специальное) и высшее), а также о доходе (разделенном на пять градаций) и роде занятий. Поскольку категория «род занятий» во многом накладывалась на предыдущие категории («пенсионер» и «студент» накладывались на возрастные категории, «домохозяйки» были исключительно женского пола, «специалисты с высшим образованием» и «служащие без высшего образования» накладывались на признак «образование»), то при расчетах эта категория создавала статистические артефакты и в итоге была исключена.

Для нас также был интересен задававшийся с 2007 по 2009 г. вопрос об образовании родителей, кодировавшийся по схеме «оба родителя без в/о», «один из родителей с в/о», «оба родителя с в/о».

В дальнейшем мы использовали два основных показателя в качестве зависимой переменной: (1) бинарную переменную, определяющую, был ли индивид хотя бы на одном представлении драматического или музыкального театра, концерте музыки академических жанров, на выставке/в музее (список активностей, отождествленных с высокой культурой ${ }^{15}$ ) за последние 12 месяцев и (2) данные о количестве мероприятий данных типов, которые индивид посетил (вычислялись как сумма заявленных посещений за последние 12 месяцев; если указывался интервал «4-6», приписывалось значение 5, «7-9» оценивалось в 8, «10 и более» - 10).

Поскольку распределение количества посещений очень далеко от нормального, мы не могли применять OLS многомерную регрессию. Различные счетные регрессии были более корректными, однако мы использовали также бинарную логистическую, поскольку она дает интуитивно понятные коэффициенты отношения шансов, в то время как коэффициенты регрессии Пуассона или биномиальной интуитивной интерпретации не имеют простой содержательной интерпретации.

15 Альфа Кронбаха для шкалы из 4 пунктов, в которую вошли бинарные переменные для этих видов активности, составила 0,882 . 


\section{Что определяет культурное потребление}

В таблице 2 приводятся коэффициенты парной корреляции Кендалла для всех задействованных переменных с указанием их статистической значимости. Почти все переменные в той или иной мере связаны друг с другом значимыми корреляциями, что вполне объяснимо при таком размере выборки.

\section{Таблица 2. Связь основных независимых переменных, корреляции Кендалла}

\begin{tabular}{|l|c|c|c|c|c|c|}
\hline & Пол & Возраст & $\begin{array}{c}\text { Образова- } \\
\text { ние }\end{array}$ & Доход & $\begin{array}{c}\text { Обра- } \\
\text { зование } \\
\text { родителей }\end{array}$ & $\begin{array}{c}\text { Куль- } \\
\text { турная } \\
\text { активность }\end{array}$ \\
\hline Пол (женский) & 1,000 & $0,054 * * *$ & $-0,006$ & $-0,164 * * *$ & $-0,003$ & $0,060^{* * *}$ \\
\hline $\mathrm{N}$ & 8997 & 8997 & 8977 & 6369 & 4600 & 8953 \\
\hline Возраст & $0,054 * * *$ & 1,000 & $-0,105 * * *$ & $-0,305 * * *$ & $-0,249 * * *$ & $-0,294 * * *$ \\
\hline $\mathrm{N}$ & 8997 & 8998 & 8978 & 6370 & 4600 & 8954 \\
\hline Образование & $-0,006$ & $-0,105^{* * *}$ & 1,000 & $0,172 * * *$ & $0,344 * * *$ & $0,273^{* * *}$ \\
\hline $\mathrm{N}$ & 8977 & 8978 & 8978 & 6365 & 4596 & 8934 \\
\hline Доход & $-0,164 * * *$ & $-0,305 * * *$ & $0,172 * * *$ & 1,000 & $0,220^{* * *}$ & $0,231^{* * *}$ \\
\hline $\mathrm{N}$ & 6369 & 6370 & 6365 & 6370 & 3003 & 6341 \\
\hline Образование родителей & $-0,003$ & $-0,249 * * *$ & $0,344 * * *$ & $0,220 * * *$ & 1,000 & $0,261 * * *$ \\
\hline $\mathrm{N}$ & 4600 & 4600 & 4596 & 3003 & 4600 & 4594 \\
\hline Культурная активность & $0,060^{* * *}$ & $-0,294 * * *$ & $0,273 * * *$ & $0,231^{* * *}$ & $0,261 * * *$ & 1,000 \\
\hline $\mathrm{N}$ & 8953 & 8954 & 8934 & 6341 & 4594 & 8954 \\
\hline
\end{tabular}

$* * * \mathrm{p}<0.001$

Женский пол респондента предсказуемо слабо коррелирует с возрастом (результат большей продолжительности жизни у женщин) и культурной активностью, отрицательно - с доходами семьи (вероятно, за счет низкодоходных домохозяйств, где женщины являются основными добытчиками). Возраст отрицательно связан с образованием (результат экспансии высшего образования в последние десятилетия), доходами и культурной активностью. Образование коррелирует с образованием родителей, предварительно подтверждая нашу гипотезу наследования. При этом надо отметить, в принципе, невысокий показатель связи между экономическим благополучием и образованием, который сам по себе говорит в пользу гипотезы статусной культуры. В Санкт-Петербурге корреляция составляет невпечатляющие 0,172 . Стереотип, согласно которому в новой капиталистической России связь между образованием и экономическим преуспеванием слаба, в общем, находит свое подтверждение.

Более сложные регрессионные модели необходимы, однако, для того, чтобы приступить к интерпретации данных о факторах культурного потребления. Результаты применения двух регрессионных техник приводятся в таблице 3. 
Таблица 3. Факторы, определяющие интенсивность культурного потребления в 2005-2011 гг.; коэффициенты логистической и негативной биномиаль ной регрессии $(\mathrm{N}=\mathbf{8 9 4 9})$, в скобках - стандартные отклонения ${ }^{16}$

\begin{tabular}{|c|c|c|c|}
\hline & \multicolumn{2}{|c|}{ Модель А (логистическая регрессия) } & \multirow{2}{*}{$\begin{array}{c}\text { Модель Б } \\
\text { (негативная } \\
\text { биномиальная) }\end{array}$} \\
\hline & B & Отношения шансов & \\
\hline Пол (мужской) & $\begin{array}{c}-0,504 * * * \\
(0,048)\end{array}$ & 0,604 & $\begin{array}{c}0,487 * * * \\
(0,258)\end{array}$ \\
\hline Возраст & $\begin{array}{c}-0,044 * * * \\
(0,008)\end{array}$ & 0,957 & $\begin{array}{c}-0,023 * * * \\
(0,005)\end{array}$ \\
\hline Образование (среднее) & $\begin{array}{c}0,270 \\
(0,479)\end{array}$ & 1,310 & $\begin{array}{c}0,913 * * * \\
(0,314)\end{array}$ \\
\hline Образование (высшее) & $\begin{array}{c}1,171^{* * * *} \\
(0,480)\end{array}$ & 3,224 & $\begin{array}{c}1,267 * * * \\
(0,313)\end{array}$ \\
\hline Доход низший & $\begin{array}{l}-0,546^{*} \\
(0,255)\end{array}$ & 0,579 & $\begin{array}{l}-0,148 \\
(0,145)\end{array}$ \\
\hline Доход ниже среднего & $\begin{array}{c}-0,663 * * * \\
(0,206)\end{array}$ & 0,515 & $\begin{array}{c}-0,334 * * \\
(0,115)\end{array}$ \\
\hline Доход средний & $\begin{array}{c}0,176 \\
(0,212)\end{array}$ & 1,192 & $\begin{array}{l}-0,074 \\
(0,108)\end{array}$ \\
\hline Доход выше среднего & $\begin{array}{c}0,085 \\
(0,238)\end{array}$ & 1,089 & $\begin{array}{l}-0,062 \\
(0,119)\end{array}$ \\
\hline Доход высший & $\begin{array}{c}-0,342 \\
(0,246)\end{array}$ & 0,711 & $\begin{array}{c}-0,151 \\
(0,119)\end{array}$ \\
\hline Возраст * образование (среднее) & $\begin{array}{c}0,014 \\
(0,008)\end{array}$ & 1,014 & $\begin{array}{c}0,005 \\
(0,005)\end{array}$ \\
\hline Возраст * образование (высшее) & $\begin{array}{l}0,015^{*} \\
(0,008)\end{array}$ & 1,015 & $\begin{array}{l}0,013 * * \\
(0,005)\end{array}$ \\
\hline Возраст * доход (низший) & $\begin{array}{l}0,005 \\
(0,005)\end{array}$ & 1,005 & $\begin{array}{l}-0,005 \\
(0,003)\end{array}$ \\
\hline Возраст * доход (второй) & $\begin{array}{l}0,010^{*} \\
(0,014)\end{array}$ & 1,010 & $\begin{array}{c}0,002 \\
(0,002)\end{array}$ \\
\hline Возраст * доход (третий) & $\begin{array}{c}0,001 \\
(0,004) \\
\end{array}$ & 1,001 & $\begin{array}{c}0,001 \\
(0,002) \\
\end{array}$ \\
\hline Возраст * доход (четвертый) & $\begin{array}{c}0,005 \\
(0,005)\end{array}$ & 1,005 & $\begin{array}{l}0,006^{*} \\
(0,003)\end{array}$ \\
\hline Возраст * доход (высший) & $\begin{array}{c}0,019 * * * \\
(0,006)\end{array}$ & 1,019 & $\begin{array}{c}0,009 * * * \\
(0,001)\end{array}$ \\
\hline Показатели качества модели & $\begin{array}{r}-2 \text { Л } \\
\text { Псевдо-R } \\
\text { Псевдо-R }\end{array}$ & $\begin{array}{l}\text { доподобие } \\
, 076 \\
\text { и Снелла } 0.145 \\
\text { желкерке } 0.195\end{array}$ & $\begin{array}{c}\text { Лог-правдоподобие } \\
-20851,593\end{array}$ \\
\hline
\end{tabular}

$* \mathrm{p}<0.05$

$* * \mathrm{p}<0.01$

$* * * \mathrm{p}<0.001$

16 Базой для сравнения по образованию служила категория «незаконченное среднее», для сравнения по доходам - затруднение или отказ от ответа. 
Как показывают коэффициенты для логистической регрессии с фактом участия в высококультурной жизни в качестве зависимой переменной, основные эффекты всех переменных значимы: шансы мужчин быть культурно активными составляют примерно $60 \%$ от шансов женщин, каждый прожитый год сокращает шансы на участие примерно на 4,3\%, люди с высшим образованием в 3,2 раза с большими шансами будут участвовать в культурной жизни, чем люди, не имеющие его. Доход также значим, хотя коэффициенты менее определенны: самый большой разрыв разделяет тех, чьи доходы «средние» и «ниже среднего», а самая высокодоходная группа показывает результаты ниже, чем у большинства других групп (но надо иметь в виду, что высшие и низшие доходные группы были представлены сравнительно небольшим числом людей в выборке).

Интеракция между возрастом и образованием оказывается незначимой: влияние уровня образования представляется постоянным на протяжении всей жизни, и эффекта стратегической смены приоритетов не просматривается. Мы не видим никаких следов того, что люди, сделавшие ставку на культурность в отдаленном прошлом, в нынешнем состоянии менее склонны вести соответствующий образ жизни, чем те, кто сделал эту ставку недавно. Скорее, если какая-то статистическая тенденция и наличествует в данных, то прямо противоположная: для старших групп высшее образование лучше предсказывает их текущее потребление, чем для младших (тенденция достигает, однако, лишь уровня значимости 0,05 ).

Значимая интеракция с доходами существует, но не в том направлении, которое предполагает логика теории культурного воспроизводства: влияние доходов на участие в культурной жизни выше среди старших групп, чем среди младших. Высокие доходы скорее сказываются на продолжительности культурной активности, чем на вероятности ее начала. Иными словами, нет никаких свидетельств того, что в России статусная культура была перехвачена восходящими классами.

Модель Б проверяет эти результаты на прочность с использованием другого метода - негативной биномиальной регрессии, рассчитанной с использованием общего числа посещенных культурных мероприятий как зависимой переменной. Мы вновь обнаруживаем позитивную связь доходов с возрастом: высокий доход продлевает период культурной активности. Кроме того, теперь значимой оказывается также интеракция возраста и образования: чем старше индивиды, тем сильнее связь между образованием и их текущей культурной активностью.

Как объяснить этот оказавшийся устойчивым статистический эффект? Он, безусловно, может служить аргументом в пользу нерефлексивности: выбор в пользу статусной культуры делается однажды и, вероятно, даже не вполне осознается в качестве выбора. Существует, однако, и еще один фактор, который наши прежние рассуждения не учитывали. Экспансия высшего образования в последние десятилетия отчасти размыла ассоциацию между обладанием университетским дипломом и принадлежностью к числу хранителей высокой культуры. Если прежде среди сравнительно небольшого числа людей с высшим образованием была высока концентрация тех, для кого «интеллигенция» была основной референтной группой, а принадлежность к статусной культура - основной жизненной ставкой, то сейчас их ряды несколько разбавились менее преданными этому идеалу индивидами. Этот эффект мог существенно затмить все прочие эффекты, связанные с изменением ролевых ориентиров на протяжении индивидуальной биографии. Так или иначе, мы явно не видим свидетельств того, что индивиды часто пересматривают свое отношение к высокой культуре в течение жизни. 
Таблица 4. Факторы, определяющие интенсивность культурного потребления в 2007-2009 гг. с учетом образования родителей. Коэффициенты логисти ческой регрессии $(\mathrm{N}=4595)$

\begin{tabular}{|c|c|c|c|c|c|c|}
\hline & \multicolumn{2}{|c|}{ Модель 1} & \multicolumn{2}{|c|}{ Модель 2} & \multicolumn{2}{|c|}{ Модель 3} \\
\hline & B & $\begin{array}{c}\text { Отно- } \\
\text { шения } \\
\text { шансов }\end{array}$ & B & $\begin{array}{c}\text { Отно- } \\
\text { шения } \\
\text { шансов }\end{array}$ & B & $\begin{array}{l}\text { Отно- } \\
\text { шения } \\
\text { шансов }\end{array}$ \\
\hline Пол (мужской) & $\begin{array}{c}-0,532 * * * \\
(0,068)\end{array}$ & 0,588 & $\begin{array}{c}-0,534 * * * \\
(0,068)\end{array}$ & 0,586 & $\begin{array}{c}-0,534 * * * \\
(0,068)\end{array}$ & 0,587 \\
\hline Возраст & $\begin{array}{c}-0,028 * * * \\
(0,003)\end{array}$ & 0,972 & $\begin{array}{c}-0,032 * * * \\
(0,004)\end{array}$ & 0,969 & $\begin{array}{c}-0,032 * * * \\
(0.003)\end{array}$ & 0,969 \\
\hline Образование (среднее) & $\begin{array}{c}1,022 * * * \\
(0,248)\end{array}$ & 2,780 & $\begin{array}{c}0,992 * * * \\
(0,249)\end{array}$ & 2,697 & $\begin{array}{c}0,990 * * * \\
(0,249)\end{array}$ & 2,692 \\
\hline Образование (высшее) & $\begin{array}{l}1,924 * * * \\
(0,249)\end{array}$ & 6,847 & $\begin{array}{c}1,894 * * * \\
(0,250)\end{array}$ & 6,646 & $\begin{array}{c}1,891 * * * \\
(0,250)\end{array}$ & 6,629 \\
\hline Доход низший & $\begin{array}{l}-0,396 \\
(0,411)\end{array}$ & 0,673 & $\begin{array}{c}-0,468 \\
(0,413)\end{array}$ & 0,626 & $\begin{array}{l}-0,467 \\
(0,409)\end{array}$ & 0,627 \\
\hline Второй квантиль & $\begin{array}{c}-1,033 * * \\
(0,239)\end{array}$ & 0,356 & $\begin{array}{c}-1,080 * * * \\
(0,219)\end{array}$ & 0,340 & $\begin{array}{c}-1,070 * * * \\
(0,298)\end{array}$ & 0,343 \\
\hline Третий квантиль & $\begin{array}{l}-0,143 \\
(0,313)\end{array}$ & 0,867 & $\begin{array}{l}-0,161 \\
(0,312)\end{array}$ & 0,851 & $\begin{array}{l}-0,168 \\
(0,312)\end{array}$ & 0,846 \\
\hline Четвертый квантиль & $\begin{array}{l}-0,185 \\
(0,334)\end{array}$ & 0,831 & $\begin{array}{l}-0,180 \\
(0,334)\end{array}$ & 0,835 & $\begin{array}{l}-0,186 \\
(0,334)\end{array}$ & 0,831 \\
\hline Доход высший & $\begin{array}{c}0,209 \\
(0,402)\end{array}$ & 1,232 & $\begin{array}{c}0,221 \\
(0,400)\end{array}$ & 1,247 & $\begin{array}{c}0,226 \\
(0,400)\end{array}$ & 1,254 \\
\hline $\begin{array}{l}\text { Возраст * доход } \\
\text { (низший) }\end{array}$ & $\begin{array}{c}0,000 \\
(0,007)\end{array}$ & 1,000 & $\begin{array}{c}0,002 \\
(0,007)\end{array}$ & 1,002 & $\begin{array}{c}0,002 \\
(0,007)\end{array}$ & 1,002 \\
\hline $\begin{array}{l}\text { Возраст * доход } \\
\text { (второй) }\end{array}$ & $\begin{array}{c}0,015 \\
(0,006)\end{array}$ & 1,015 & $\begin{array}{l}0,016^{* *} \\
(0,006)\end{array}$ & 1,016 & $\begin{array}{l}0,015^{* *} \\
(0,006)\end{array}$ & 1,015 \\
\hline $\begin{array}{l}\text { Возраст * доход } \\
\text { (третий) }\end{array}$ & $\begin{array}{c}0,005 \\
(0,007)\end{array}$ & 1,005 & $\begin{array}{c}0,005 \\
(0,007)\end{array}$ & 1,005 & $\begin{array}{c}0,005 \\
(0,007)\end{array}$ & 1,005 \\
\hline $\begin{array}{l}\text { Возраст * доход } \\
\text { (четвертый) }\end{array}$ & $\begin{array}{c}0,011 \\
(0,007)\end{array}$ & 1,012 & $\begin{array}{c}0,011 \\
(0,007)\end{array}$ & 1,011 & $\begin{array}{c}0,011 \\
(0,007)\end{array}$ & 1,011 \\
\hline $\begin{array}{l}\text { Возраст * доход } \\
\text { (высший) }\end{array}$ & $\begin{array}{c}0,008 \\
(0,009)\end{array}$ & 1,008 & $\begin{array}{c}0,008 \\
(0,009)\end{array}$ & 1,008 & $\begin{array}{c}0,008 \\
(0,009)\end{array}$ & 1,008 \\
\hline $\begin{array}{l}\text { Образование родите- } \\
\text { лей (среднее) }\end{array}$ & $\begin{array}{c}0,286^{* * *} \\
(0,085)\end{array}$ & 1,331 & $\begin{array}{c}0,135 \\
(0,239) \\
\end{array}$ & 1,145 & & \\
\hline $\begin{array}{l}\text { Образование родите- } \\
\text { лей (высшее) }\end{array}$ & $\begin{array}{c}0,362 * * * \\
(0,090)\end{array}$ & 1,436 & $\begin{array}{c}-0,047 \\
(0,237)\end{array}$ & 0,954 & & \\
\hline $\begin{array}{l}\text { Возраст * образование } \\
\text { родителей (среднее) }\end{array}$ & & & $\begin{array}{c}0,003 \\
(0,005)\end{array}$ & 1,003 & $\begin{array}{l}0,006^{* *} \\
(0,002)\end{array}$ & 1,006 \\
\hline $\begin{array}{l}\text { Возраст * образование } \\
\text { родителей (высшее) }\end{array}$ & & & $\begin{array}{c}0,009 \\
(0,005)\end{array}$ & 1,009 & $\begin{array}{c}0,008 * * * \\
(0,002)\end{array}$ & 1,008 \\
\hline $\begin{array}{l}\text { Показатели качества } \\
\text { модели }\end{array}$ & \multicolumn{2}{|c|}{$\begin{array}{c}\text {-2 Лог-правдоподобие } \\
5452,241 \\
\text { Псевдо-R }{ }^{2} \text { Кокса } \\
\text { и Снелла 0,164 } \\
\text { Псевдо-R }{ }^{2} \text { Найджелкерке } \\
0,221\end{array}$} & \multicolumn{2}{|c|}{$\begin{array}{c}-2 \text { Лог-правдоподобие } \\
5448,773 \\
\text { Псевдо-R Кокса } \\
\text { и Снелла } 0,165 \\
\text { Псевдо- } \mathrm{R}^{2} \text { Найджелкерке } \\
0,222\end{array}$} & \multicolumn{2}{|c|}{$\begin{array}{c}-2 \text { Лог-правдоподобие: } \\
5449,297 \\
\text { Псевдо-R Кокса } \\
\text { и Снелла: } 0,165 \\
\text { Псевдо-R }{ }^{2} \text { Найджелкер- } \\
\text { ке: } 0,222 \\
\end{array}$} \\
\hline
\end{tabular}

\footnotetext{
$* \mathrm{p}<0.05$

$* * \mathrm{p}<0.01$

$* * * \mathrm{p}<0.001$
} 
Эти рассуждения подкрепляются данными таблищзы 4. Здесь на подвыборке 2007-2009 гг. тестировалась модель, идентичная Модели А из таблищьь 3, но с дополнительной переменной «образование родителей» (Модель 1). Затем мы рассчитали Модель 2, из которой убрали интеракцию возраста с собственным образованием и добавили интеракцию возраста с образованием родителей.

Прежде всего, надо отметить, что образование родителей оказывается высоко значимой переменной, которая существенно улучшает общее качество модели. Как мы видим (и как нас обязывает предполагать идея наследственной статусной культуры), дети из интеллигентских семей имеют больше шансов усвоить соответствующие поведенческие паттерны и жить сообразно им. Когда мы вводим дополнительно интеракцию образования родителей с возрастом, то обнаруживаем, что обе переменные стали незначимыми (хотя интеракция высшего образования обоих родителей и возраста приближается к значимости). Однако, исключив высшее образование родителей как таковое и оставив только интеракцию (Модель 3), мы вновь получаем значимый эффект интеракции. В целом есть основания полагать, что образование родителей (происхождение из «культурной» семьи) лучше предсказывает нынешнее поведение старших групп, чем младших. Мы не видим свидетельств того, что влияние семьи сокращается по мере того, как развертывается собственная жизненная траектория индивида. Это вновь указывает в пользу существования ядра носителей статусной культуры, границы которого прежде совпадали или приблизительно совпадали с границами имеющей высшее образование группы, однако затем вторая расширилась, и степень пересечения сократилась.

Наконец, мы пересчитали Модель 1 для двух подвыборок, в одну из которых вошли индивиды до 46 лет включительно (медианный возраст в нашей выборке), а во вторую - те, кто был старше 46. Для первой подвыборки Псевдо-R ${ }^{2}$ Кокса и

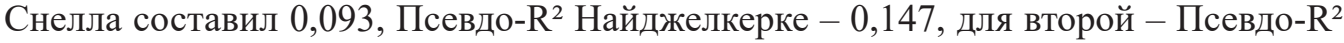
Кокса и Снелла - 0,186, Псевдо-R ${ }^{2}$ Найджелкерке - 0,248. Иными словами, наши базовые социальные характеристики значительно лучше прогнозируют поведение старшей когорты, чем младшей.

\section{Выводы и дискуссионные соображения}

К каким общим выводам мы можем прийти? Прежде всего, как и результаты, описанные в нашей предыдущей статье, так и анализируемые здесь данные противоречат предположению о том, что принадлежность к статусной культуре производна от классовой принадлежности. Корреляции между культурным потреблением и доходами слабые, причем нет интерактивных эффектов, которые свидетельствовали бы о том, что это ослабление - явление сугубо временное, связанное с тем, что новые богатые еще не освоились с символами своего богатства. Исследование российского случая может служить сильным аргументом для общей теории, обосновывающей возможность статуса, независимого от экономического класса в современных обществах.

Является ли поддержание принадлежности сознательными выбором или простым отыгрыванием усвоенных в детстве моделей? Выше мы говорили о том, что ослабление связи образования индивида и образования его родителей и текущего 
культурного потребления с возрастом могло бы трактоваться как свидетельство высокой рефлексивности, т.е. того факта, что люди пересматривают свои инвестиции в зависимости от обстоятельств. На примере нашей выборки, однако, мы видим нечто прямо противоположное: данные говорят о том, что причастность к статусной культуре демонстрирует значительное постоянство на протяжении жизненной траектории. С другой стороны, то, что период самой интенсивной культурной жизни приходится на ранние года, может считаться указанием на то, что люди задаются сознательной целью утвердить принадлежность к ней в сравнительно раннем возрасте. По мере того, как цель оказывается достигнутой, а социальный круг, к которому индивид принадлежит, складывается, инвестиции в культурное потребление сокращаются, хотя и в меньшей степени среди тех, кто имеет больше всего оснований ощущать себя «настоящей интеллигенцией». И тем, и другим фактам, однако, можно дать иную трактовку, и мы не можем, таким образом, вынести окончательного вердикта по этому поводу, поскольку «улики» оказываются в лучшем случае косвенными.

Теория культурного воспроизводства хуже всего объясняет наличные факты. То, что культурная активность сокращается с возрастом, при этом доход сильнее сказывается на активности старших групп, нежели младших, прямо противоречит представлениям о том, что наше культурное участие есть отпечаток габитуса, который, в свою очередь, отражает классовый опыт раннего детства. Культурная мобильность и демонстративное потребление, однако, выглядят немногим лучше: слабые корреляции культурности с доходами и положительные интеракции возраста с доходами плохо вписываются в представления о том, что культурный уровень - это сознательная инвестиция в сигналы, которые могут способствовать классовой мобильности.

Теория стилистического плюрализма позволяет сделать несколько важных и контринтуитивных предположений, особенно в отношении младших когорт. Она объясняет, почему высшее образование обладает меньшей предсказательной силой для младших возрастных групп и почему их участие в практиках культурности слабее прогнозируется социоструктурными переменными, чем участие старших. Однако эти выводы нельзя считать окончательными: отрицательная интеракция с возрастом может быть результатом массовизации высшего образования, а меньшая структурная обусловленность участия - тем, что в юности люди примеряют на себя самые разные идентичности, с возрастом останавливаясь на какой-то одной. Их поведение в период биографических экспериментов может быть малопредсказуемо, однако то, какую идентичность они для себя выберут в итоге, уже предрешено, хотя им самим в тот момент об этом еще неизвестно. Так ли это, мы узнаем по прошествии некоторого времени, когда можно будет сравнить, росла ли объяснительная сила базовых социальных характеристик по мере того, как соответствующее поколение старело. Динамические данные, которыми мы располагаем, указывают, скорее, на то, что мы имеем дело с эффектами жизненного цикла: в каждый момент времени самые юные оказываются самыми культурными, однако по мере того, как каждая следующая когорта стареет, в ее культурной активности ощущается спад [Илле, Соколов 2018]. И даже если стилистическая плюрализация наступает, то тот факт, что образование родителей - значимая переменная даже для самых младших респондентов, показывает, что свобода выбора жизненных стилей остается пока ограниченной. 
Наконец, теория статусной автономии противоречит нашим данным по наименьшему числу пунктов. За исключением некритичного для нее предсказания о постоянстве роли социоструктурных переменных, мы не находим ничего, что прямо противоречило бы ей. Тем не менее по ее поводу нужно сделать оговорку. Как мог заметить читатель, глядя на таблицу 1, из теории статусной автономии вообще не следует конкретных прогнозов в отношении поведения наших переменных, и в этом смысле с их помощью ее фальсифицировать невозможно. Она, скорее, представляет собой остаточное объяснение, позволяющее ответить, почему все прочие терпят крах. Ясно несовершенство такого доказательства, однако на данный момент это лучшая догадка, которую мы можем сделать на основании полученных данных. Мы предполагаем, что статус, независимый от экономических шансов, доступ к которому давала в том числе и культурность, существовал в СССР и продолжил существовать в постсоветских обществах, и что индивиды инвестируют время и силы в его достижение (в особенности когда они молоды, и сделанный вклад может оказать влияние на их социальную траекторию, а время и силы еще не поглощены профессиональными или семейными обязательствами). При этом решение примерять на себя амплуа «культурного» или «некультурного» человека частично объясняется появлением на свет в «культурной семье». Возможно, выбор каждой следующей когорты меньше детерминирован происхождением и прочими структурными переменными, чем выбор предыдущей, но у нас нет оснований для окончательных выводов на этот счет.

Постоянство среды, воспроизводящей статусную культуру, заставляет нас, однако, задаться еще одни вопросом: уверены ли мы, что можем говорить о статусной культуре в России в единственном числе? Термин «статусная культура»у П. ДиМаджио, как и, например, «легитимное искусство» у П. Бурдье, предполагает, что знакомство с ней является источником общесоциального престижа, и исключена ситуация, когда группа А предполагает, что она обладает большим престижем, чем Б, а группа Б думает то же самое про себя. Мы можем задаться здесь вопросом о том, в какой мере граница культурности осознается одинаково теми, кто находится по ее разные стороны; имеет ли место повсеместно признаваемое превосходство одного стиля жизни, или носители разных стилей жизни считают себя стоящими выше? Может ли быть так, что за пределами группы, приписывающей культурности значительную ценность, находятся группы, не приписывающие ей никакой ценности вовсе? Наши данные, разумеется, не проливают на это свет. Так или иначе, мы можем утверждать, что число тех, для кого традиционная высокая культура окружена ореолом, не сократилось за время социальных катаклизмов.

Обращаясь вновь к началу этой статьи, мы могли бы сказать, что ответ на вопрос, пригодна ли теория П. Бурдье для объяснения наблюдаемых нами паттернов, преимущественно отрицателен. И культурное воспроизводство, и другие теории, предполагающие производность статуса, не совсем правильно описывают наш случай. Здесь надо сделать важную оговорку: невозможно автоматически перейти от вывода о том, что теория П. Бурдье не приемлема на нашей выборке, к положению о том, что она не применима в России (имея в виду, что она «работает» на Западе, а ее слабость здесь обусловлена российской уникальностью). Исследования последних лет ставят под сомнения, что многие описанные им феномены (в первую очередь культурный снобизм элит) в действительности характерны даже для Франции сегодня [Coulangeon, Lemel 2007] или были 
характерны для всех европейских стран в прошлом [Jaeger, Katz-Gerro 2010]. Пока не проведен обстоятельный метаанализ, мы не можем делать выводы о кросс-национальных отличиях.

Тем не менее, не дожидаясь этого метаанализа, мы можем выдвинуть несколько предположений относительно российской специфичности. Одна возможность состоит в том, что механизм, описанный в западных теориях производности, применим и к ней, но с той поправкой, что статусная культура общеевропейского образца была поставлена здесь на службу неклассовым по своей природе общностям. В данном случае тезис о неавтономности статусной культуры возвращается к нам в новом обличье. Что случится, если культурный капитал в России станет символом принадлежности к привилегированному слою, который имеет устойчиво неклассовую основу [Бессонова 1998; Кордонский 2008]? Действительно, само существование в России классов, аналогичных тем, которые подразумевали П. Бурдье и П. ДиМаджио, находится под вопросом. В стране с хронически незащищенными правами собственности стабильное доминирование, основанное на наследственном богатстве, вряд ли могло возникнуть.

С другой стороны, возможно, что и в России, и даже за ее пределами, обаяние культурности и привлекательность образа жизни, частью которого она стала, все же фундаментально несводимы к классу. Ощущение себя «культурным» воспринимается значительной частью людей как самоценность, или, во всяком случае, эти люди предполагают, что им следовало бы обращаться с культурностью как с самоценностью и их неспособность соответствовать стандартам вызовет осуждение. Способность или неспособность соответствовать идеалу культурности задают свою собственную социальную иерархию, не сводящуюся к богатству или какой-то форме социальной привилегии. В этом смысле культурность подобна, например, телесной гигиене, пренебрежение которой станет стигматизирующим признаком, какую бы социальную позицию ни занимал индивид, и, наоборот, следование ей одобряется, кто бы его ни демонстрировал. В данном случае, в отличие от гигиены, мы говорим скорее о практике, которая служит особым отличием для тех, кто ее придерживается, а не стигмой для тех, кто от нее уклоняется, но общая логика, вероятно, будет той же. Культурность, как и, например, миловидность, дружелюбие или мастерство рассказчика, могут легче даваться представителям высшего слоя, но ценятся они вовсе не потому, что являются его символами или облегчают доступ в него. Они не перестанут служить материалом для построения социальной идентичности, даже если эта идентичность и не будет иметь никакого употребления как инструмент классового исключения.

\section{Литература}

Банк Б.В., Виленкин А.Я. (1927) Деревенская беднота и библиотека. Опыт исследования читательских интересов. Л.: «Гудок».

Бессонова О.Э. (1998) Теория раздаточной экономики - новый взгляд на хозяйственное развитие России // Общество и экономика. № 8-9. С. 241-255.

Бессуднов А.Р. (2009) Социально-профессиональный статус в современной России // Мир России. № 2. С. 89-116.

Веблен Т. (1984) Теория праздного класса. М.: Прогресс. 
Илле М.Е. (2016) Участие жителей «культурной столицы» в культурной жизни Петербурга // «Телескоп»: журнал социологических и маркетинговых исследований. № 5. C. 27-32.

Илле М.Е. (2017) Образ «идеального» петербуржца и культурная жизнь города // «Телескоп»: журнал социологических и маркетинговых исследований. № 4. С. 32-42.

Илле М.Е., Соколов М.М. (2018) Статусные культуры в эпоху социальной революции. Культурное потребление в Петербурге, 1991-2011 // Мир России. № 1. С. 159-182.

Кордонский С.Г. (2008) Сословная структура постсоветской России. М.: Общественное мнение.

Соколов М.М., Сафонова М.А., Чернецкая Г.А. (2017) Культурный капитал, пространство вкусов и статусные границы среди российских студентов // Мир России. № 1. С. $152-179$.

Фохт-Бабушкин Ю.У. (2001) Искусство в жизни людей (конкретно-социологические исследования искусства в России второй половины XX века. История и методология). СПб.: Алетейя.

Aschaffebburg K., Maas I. (1997) Cultural and Educational Careers: The Dynamics of Social Reproduction // American Sociological Review, vol. 62, no 4, pp. 573-587.

Atkinson W. (2011) The Context and Genesis of Musical Tastes: Omnivorousness Debunked, Bourdieu Buttressed // Poetics, vol. 39, no 3, pp. 169-186.

Bourdieu P. (1984) Distinction: The Social Critique of the Judgment of Taste, London: Routledge/Kegan Paul.

Bukodi E. (2007) Social Stratification and Cultural Consumption in Hungary: Book Readership // Poetics, vol. 35, no 2-3, pp. 112-131.

Chan T.W., Goldthorpe J.H. (2004) Is There a Status Order in Contemporary British Society? Evidence from the Occupational Structure of Friendship // European Sociological Review, vol. 20, no 5, pp. 383-401.

Chan T.W., Goldthorpe J.H. (2007) Class and Status: The Conceptual Distinction and Its Empirical Relevance // American Sociological Review, vol. 72, no 4, pp. 512-532.

Coulangeon P., Lemel Y. (2007) Is 'Distinction' Really Outdated? Questioning the Meaning of the Omnivorization of Musical Taste in Contemporary France // Poetics, vol. 35, no 2-3, pp. 93-111.

DiMaggio P., Mohr J. (1985) Cultural Capital, Educational Attainment, and Marital Selection // American Journal of Sociology, vol. 90, no 6, pp. 1231-1257.

DiMaggio P., Mohr J. (1995) The Intergenerational Transmission of Cultural Capital // Research in Social Stratification and Mobility, vol. 14, pp. 167-199.

Goffman E. (1951) Symbols of Class Status // British Journal of Sociology, vol. 11, no 1, pp. 294-304.

Holt D.B. (1997) Distinction in America? Recovering Bourdieu's Theory of Tastes from Its Critics // Poetics, vol. 25, no 2-3, pp. 93-120.

Holt D.B. (1998) Does Cultural Capital Structure American Consumption? // Journal of Consumer Research, vol. 25, no 1, pp. 1-25.

Jæger M., Katz-Gerro T. (2010) The Rise of the Eclectic Cultural Consumer in Denmark, 19642004 // Sociological Quarterly, vol. 51, no 3, pp. 460-483.

Katz-Gerro T. (2011) Cross-National Cultural Consumption Research: Inspirations and Disillusions // Kölner Zeitschrift für Soziologie und Sozialpsychologie, no 51, pp. 339-360.

Kraaykamp G., Nieuwbeerta P. (2000) Parental Background and Lifestyle Differentiation in Eastern Europe: Social, Political, and Cultural Intergenerational Transmission in Five Former Socialist Societies // Social Science Research, vol. 29, no 1, pp. 92-122.

Konrad G., Szelenyi I. (1979) Intellectuals at the Road to the Class Power, Brighton: Harvester Press.

Lenski G. (1954) Status Crystallisation: a Non-vertical Dimension of Social Status // American Sociological Review, vol. 19, no 4, pp. 405-414.

Lizardo O., Skiles S. (2012) Reconceptualizing and Theorizing "Omnivorousness": Genetic and Relational Mechanisms // Sociological Theory, vol. 30, no 4, pp. 263-282.

Shils E. (1965) Charisma, Order and Status // American Sociological Review, vol. 30, no 2, pp. 199-213. 
Weber M. (1978) Economy and Society, Berkeley: University of California Press.

Zavisca J. 2005. The Status of Cultural Omnivorism: A Case Study of Reading in Russia // Social Forces, vol. 84, no 2, pp. 1233-1255.

Благодарности

Авторы благодарят Институт культурных программ при правительстве Санкт-Петербурга за поддержку исследований в 2005-2011 гг. и Европейский университет в Санкт-Петербурге за поддержку продолжения проекта в 2017 г.; а также А.Р. Бессуднова, Ю. Гронова, Б. Долгина, К. Рахконена и М. Сафонова за помощь и комментарии.

\title{
The Social Basis of Kulturnost': Do Pierre Bourdieu, Paul DiMaggio and Others Explain Patterns of Arts Participation in a Major Russian City ${ }^{17}$
}

\author{
M. ILLE*, M. SOKOLOV**
}

\begin{abstract}
*Mikhail Ille - Senior Lecturer, Department of Philosophy and Communication studies, Saint Petersburg University of Civil Aviation; Editor, "The Telescope: Journal of Sociological and Market Research" Address: of. 508, 14, Izmajlovkij Av., Saint Petersburg, 190005, Russian Federation. E-mail: red tel@mail.ru

**Mikhail Sokolov - PhD in Sociology, Professor, Political Science and Sociology Department, European University at Saint Petersburg. Address: 3a, Gagarinskaya St., Saint Petersburg, 191187, Russian Federation. E-mail: msokolov@eu.spb.ru

Citation: Ille M., Sokolov M. (2018) The Social Basis of Kulturnost': Do Pierre Bourdieu, Paul DiMaggio and Others Explain Patterns of Arts Participation in a Major Russian City. Mir Rossii, vol.27, no 2, pp. 163-188 (in Russian). DOI: 10.17323/1811-038X-2018-27-2-163-188
\end{abstract}

\begin{abstract}
In spite of animated debates on the applicability of "Western" theorizing to the study of Russian society, so far there have been relatively few attempts to evaluate this applicability empirically. Even fewer studies test several competing theories at once; most studies which address this issue at all, tend to focus on a single theory. In this article, we evaluate the explanatory force of five competing theories of cultural consumption using a dataset from the Saint Petersburg Survey of Cultural Participation 2005-2011. We start by

17 This article is a continuation of the article "Cultural Capital, Artistic Tastes, and Status Boundaries Among the Russian University Students” published in Mir Rossii, No 1, 2018 [Ille, Sokolov 2018, pp. 159-182].
\end{abstract}


introducing these five theories - conspicuous consumption, cultural reproduction, cultural mobility, status autonomy, and lifestyle pluralization - and derive testable implications concerning the association between consumption rates and a set of basic demographic and social-structural attributes (age, education, income, parental education) and their interactions. We show that expectations consistent with Bourdieu's cultural reproduction theory show the poorest fit with the data. The theories of conspicuous consumption and cultural mobility also fail to explain the observed correlations. Our conclusion is that only status autonomy theory is consistent with observations, although some evidence of pluralization in younger cohorts is also present in the data.

Key words: sociology of culture, sociology of arts, cultural consumption, social stratification, cultural capital, social status, high culture in Russia

\section{References}

Aschaffebburg K., Maas I. (1997) Cultural and Educational Careers: The Dynamics of Social Reproduction. American Sociological Review, vol. 62, no 4, pp. 573-587.

Atkinson W. (2011) The Context and Genesis of Musical Tastes: Omnivorousness Debunked, Bourdieu Buttressed. Poetics, vol. 39, no 3, pp. 169-186.

Bank B.V., Vilenkin A.Ya. (1927) Derevenskaya bednota i biblioteka. Opyt issledovaniya chitatel'skikh interesov [The Rural Poor and the Library. A Study of Readers' Tastes], Leningrad: Gudok.

Bessonova O.E. (1998) Teoriya razdatochnoj ekonomiki - novyj vzglyad na khozyajstvennoe razvitie Rossii [The Theory of Distributive Economy. A New Look at Russia's Economic Development]. Obshchestvo i ekonomika, no 8-9, pp. 241-255.

Bessudnov A.R. (2009) Sotsial'no-professional'nyj status v sovremennoj Rossii [Social and Occupational Status in Russia]. Mir Rossii, vol. 18, no 2, pp. 89-116.

Bourdieu P. (1984) Distinction: The Social Critique of the Judgment of Taste, London: Routledge/Kegan Paul.

Bukodi E. (2007) Social Stratification and Cultural Consumption in Hungary: Book Readership. Poetics, vol. 35, no 2-3, pp. 112-131.

Chan T.W., Goldthorpe J.H. (2004) Is There a Status Order in Contemporary British Society? Evidence from the Occupational Structure of Friendship. European Sociological Review, vol. 20, no 5, pp. 383-401.

Chan T.W., Goldthorpe J.H. (2007) Class and Status: The Conceptual Distinction and Its Empirical Relevance. American Sociological Review, vol. 72, no 4, pp. 512-532.

Coulangeon P., Lemel Y. (2007) Is 'Distinction' Really Outdated? Questioning the Meaning of the Omnivorization of Musical Taste in Contemporary France. Poetics, vol. 35, no 2-3, pp. 93-111.

DiMaggio P., Mohr J. (1985) Cultural Capital, Educational Attainment, and Marital Selection. American Journal of Sociology, vol. 90, no 6, pp. 1231-1257.

DiMaggio P., Mohr J. (1995) The Intergenerational Transmission of Cultural Capital. Research in Social Stratification and Mobility, vol. 14, pp. 167-199.

Fokht-Babushkin Yu.U. (2001) Iskusstvo v zhizni ludej. Kokretno-sotsiologicheskie issledovaniya iskusstva v Rossii vtoroj poloviny XX veka [Arts in People's Life. Empirical Studies of Arts in Russia in the Second Half of the XX century], Saint Petersburg: Aleteya.

Goffman E. (1951) Symbols of Class Status. British Journal of Sociology, vol. 11, no 1, pp. 294-304. Holt D.B. (1997) Distinction in America? Recovering Bourdieu's Theory of Tastes from Its Critics. Poetics, vol. 25, no 2-3, pp. 93-120. 
Holt D.B. (1998) Does Cultural Capital Structure American Consumption? Journal of Consumer Research, vol. 25, no 1, pp. 1-25.

Ille M.E. (2016) Uchastie zhitelej "kulturnoj stolitsy" v kulturnoj zhizni Peterburga [The Participation of Citizens of "the Cultural Capital" in the Cultural Life of Saint Petersburg]. "Teleskop": zhurnal sotsiologicheskikh i marketingovykh issledovanij, no 5, pp. 27-32.

Ille M.E. (2017) Obraz “ideal'nogo" Petersburzhtsa i kulturnaya zhizn' goroda [The Image of an Ideal Saint Peterburgian and the Cultural Life of the City]. "Teleskop": zhurnal sotsiologicheskikh i marketingovykh issledovanij, no 4, pp. 32-42.

Ille M.E., Sokolov M.M. (2018) Statustnaya kultura i ekonomicheskaya transformatsiya. Kulturnoe potreblenie v Petersburge, 1991-2011 [Status Culture in the Times of Economic Transformation. Cultural Participation in Saint Petersburg, 1991-2011]. Mir Rossii, no 1, pp. 159-182.

Jæger M., Katz-Gerro T. (2010) The Rise of the Eclectic Cultural Consumer in Denmark, 1964-2004. Sociological Quarterly, vol. 51, no 3, pp. 460-483.

Katz-Gerro T. (2011) Cross-National Cultural Consumption Research: Inspirations and Disillusions. Kölner Zeitschrift für Soziologie und Sozialpsychologie, no 51, pp. 339-360.

Kraaykamp G., Nieuwbeerta P. (2000) Parental Background and Lifestyle Differentiation in Eastern Europe: Social, Political, and Cultural Intergenerational Transmission in Five Former Socialist Societies. Social Science Research, vol. 29, no 1, pp. 92-122.

Konrad G., Szelenyi I. (1979) Intellectuals at the Road to the Class Power, Brighton: Harvester Press.

Kordonskij S.G. (2008) Soslovnaya struktura postsovetskoj Rossii [The Estate Structure of Post-Soviet Russia], Moscow: Obshchestvennoe mnenie.

Lenski G. (1954) Status Crystallisation: a Non-vertical Dimension of Social Status. American Sociological Review, vol. 19, no 4, pp. 405-414.

Lizardo O., Skiles S. (2012) Reconceptualizing and Theorizing “Omnivorousness": Genetic and Relational Mechanisms. Sociological Theory, vol. 30, no 4, pp. 263-282.

Shils E. (1965) Charisma, Order and Status. American Sociological Review, vol. 30, no 2, pp. 199-213.

Sokolov M.M.. Safonova M.A., Chernetskaya G.A. (2017) Kulturnyj kapital, prostranstvo vkusov i statusnye granitsy sredi rossijskikh studentov [Cultural Capital, Artistic Tastes, and Status Boundaries Among the Russian University Students]. Mir Rossii, no 1, pp. 152-179.

Veblen T. (1984) Teoriya prazdnogo klassa [The Theory of the Leisure Class], Moscow: Progress.

Weber M. (1978) Economy and Society, Berkeley: University of California Press.

Zavisca J. 2005. The Status of Cultural Omnivorism: A Case Study of Reading in Russia. Social Forces, vol. 84, no 2, pp. 1233-1255. 